\title{
Okul Müdürlerinin Görüşlerine Göre Diyarbakır İli Eğitim Sorunları ve Çözüm Önerileri*
}

\author{
Abidin DAĞLI1, Bünyamin HAN2 \\ ${ }^{1}$ Yrd.Doç.Dr., Dicle Üniversitesi,dagli@dicle.edu.tr \\ ${ }^{2}$ Arş. Gör., Dicle Üniversitesi, bunyaminhan@gmail.com
}

Bu araştırmanın amacı, kamu illkokullarında görevli okul müdürlerinin eğitim-öğretim sürecinde karşılaştıkları sorunlar ve bu sorunların çözümüne yönelik önerilerinin neler olduğunu saptamaktır. Çalışmada nitel araştırma desenlerinden durum çalışması kullanılmıştır. Araştırmanın çalışma gurubunu Diyarbakır il merkezindeki kamu ilkokullarında görevli 20 okul müdürü oluşturmaktadır. Veri toplama aracı olarak araştırmacılar tarafindan hazırlanan yarı yapılandırılmış görüşme formu kullanılmıştır. Görüşme formlarından elde edilen veriler içerik analizi tekniğiyle analiz edilerek kodlar ve temalar oluşturulmuştur. Araştırmada okul müdürlerinin eğitim öğretim sürecinde en sık karşılaştıkları sorunlar sırasıyla; (1) okulun fiziki sorunları, (2) yönetim ile ilgili karşılaştıkları sorunlar, (3) öğretmenler ile ilgili karşılaştıkları sorunlar, (4) veliler ile ilgili karşılaştıkları sorunlar ve (5) öğrenciler ile ilgili karşılaştıkları sorunlardır. Araştırma sonunda bu sorunların çözümüne yönelik çeşitli öneriler sunulmuştur.

Anahtar Kelimeler: Diyarbakır, Eğitim sorunları, Okul müdürü

\section{Educational Problems of Diyarbakır and Their Solutions According to Principal Views}

\begin{abstract}
The purpose of this research is to determine the educational problems faced by school principals working in the center of Diyarbakir province and to propose solutions for these problems. In the research, from the qualitative research methods case study was used. The study group of the research is composed of 20 school principals working in the primary schools in Diyarbakır. Quasi-structured interview form prepared by the researchers was used as data collection tool. The data obtained from interview forms were analyzed by content analysis technique and codes and themes were created. Some important results obtained in the research are as follows: According to the opinions of the principals the most common problems in the education and training process are; (1) physical problems, (2) management problems, (3) problems with teachers, (4) problems with parents and (5) problems with students. At the end of the research, some suggestions for solution of these problems were presented.
\end{abstract}

Keywords: Diyarbakır, Educational problems, Principals

\section{GİRİ̧̧}

Eğitim sisteminin amacı, bireyleri istendik amaçlar doğrultusunda yetiştirmektir. Toplum da okullara emanet ettiği gençleri en iyi şekilde eğitildiğini görmek istemektedir. Okulların bu misyonunu yerine getirebilmeleri birçok faktöre bağlıdır. Bu faktörlerin başında da, yöneticiler, öğretmenler ve veliler gelmektedir. Ancak, okulların amaçlarının gerçekleştirilmesinde birinci derecede okul yöneticileri sorumludur. “Bir okulun etkililiği ve başarısı, büyük ölçüde o okulun yöneticisinin yetkinliği ve niteliği ile ilişkilendirilebilir. Okulların kalitesinin artırılmasında en önemli rol okul yöneticilerinindir" (Karip, 2004). Eğitim yöneticilerinin bir görevi, eğitim örgütlerini amaçlarına ulaştırmak için elde var olan insan ve maddî kaynaklarının etkili ve verimli bir şekilde kullanımının sağlanmasıdır (Kayıkçı, 2001).

\footnotetext{
* Bu çalışma, Dicle Üniversitesi, Bilimsel Araştırmalar Koordinatörlüğü (DÜBAP) tarafindan desteklenen ZGEF.16. 017 proje numaralı "Diyarbakır İli Ë̆itim Sorunlar ve Çözüm Önerileri’” başlıklı proje kapsamında hazırlanmıştır.
} 
Okul yöneticisinden yetkilendirici, katılımc1, dönüşümcü, kolaylaştırıc1, etik ve eğitici-öğretici bir lider olması beklenmektedir (Aytaç, 2002). İdeal okul yöneticilerinden; çalışanların moralini, motivasyonunu, performansını ve iş doyumunu arttırıcı davranışlar sergilemesi beklenmektedir. Okul yöneticileri şu yeterlikleri taşımalıdırlar: Okul kaynaklarını etkili şekilde yönetebilme, okul düzenini sağlama, okul aktivitelerinin devamını sağlama, personelin gelişimini sağlama, öğretim programının uygulanmasına ve değişimine rehberlik etme, okulda ödül sistemini, değerlendirme ve kalite yönetim sistemlerini yönetebilme, karar sürecine okulun diğer üyelerini de katarak okulda etik ilkeler oluşturma (Mestry ve Grobler, 2004: 5). Recepoğlu ve Kıllnç (2014) da, okulların amaçlarına ulaşabilmesi için okuldaki yöneticilerin, çalışanların ve öğrencilerin hep birlikte hareket etmesi, kararlara katılması, herkesin özgürce kendi düşüncesini söyleyebilmesi, uygulamaları ve alınan kararları benimsemesi gerektiğini ve bunun büyük bir önem taşıdığını ileri sürmektedir. "Okul yöneticileri okullarındaki kurumsal uygulamaları çok iyi bilmeleri ve dolayısıyla öğretimsel liderlik davranışları sergilemeleri gerekmektedir (Campos, Gomez ve Shen, 2005: 310). Okul yöneticisinin öğretimsel liderliği okuldaki öğrenme iklimini, uzmanlaşmayı, öğretmen bağlılı̆̆ını, öğrenci başarısını ve öğretmenlerin moralini etkilemektedir (Anderson, 1991: 21, 22).

Okul yöneticileri, yönetim görevlerini yerine getirirken birçok sorunla karşılaşabilirler. Bu sorunların kaynağı okul örgütünün farklı bileşenleri olabileceği gibi okul dışından etmenler de olabilir. Yaşanan sorunların kaynaklarından bazıları olarak; öğrenciler, öğretmenler, okul bina ve demirbaşları, okulun bulunduğu bölgenin sosyal, kültürel, politik ve ekonomik özellikleri, okulun kültürü ve iklimi, hatta okul yöneticilerinin sahip oldukları yönetim becerileri sayllabilir (Demirtaş, Üstüner ve Özer, 2007: 422). Okul yöneticileri çeşitli kaynaklardan gelen çok boyutlu sorunları, okulun kendine özgü yönlerini de dikkate alarak, demokratik bir biçimde çözmek ve okulu amaçları doğrultusunda yaşatmak zorundadırlar (Dönmez, 2001: 63). İşte okul yöneticilerinin eğitim-öğretim sürecinde karşılaştıkları sorunlarının tespit edilmesi ve bu sorunlara yönelik ileri sürdükleri önerilerinin neler olduğunun ortaya çıkartılması, üstlenmiş oldukları rolleri etkili bir şekilde oynamaları açısından büyük önem arz etmektedir.

Yapılan literatür taramasında, Diyarbakır il merkezindeki kamu ilkokullarında görevli müdürlerin görüşlerine dayalı olarak eğitim-öğretim sürecinde en sık karşılaştıkları sorunlara ve bu sorunların çözümüne ilişkin herhangi bir araştırmaya rastlanamamıstır. İşte bu araştırma ile Diyarbakır il merkezindeki kamu ilkokullarında görevli okul müdürlerinin görüşlerine dayalı olarak eğitim-öğretim sürecinde en sık karşılaştıkları sorunlar ve bu sorunlara ilişkin çözüm önerilerinin neler olduğu ortaya çıkartmak amaçlanmıştır.

\subsection{Araştırmanın Amacı}

$\mathrm{Bu}$ araştırmanın amacı, Diyarbakır il merkezindeki kamu ilkokullarında görevli okul müdürlerinin görüşlerine dayalı olarak eğitim-öğretim sürecinde en sık karşılaşılan sorunlar ve bu sorunların çözümüne ilişkin önerilerinin neler olduğunu ortaya çıkartmaktır.

\section{YÖNTEM}

Bu bölümde araştırma modeli, çalışma grubu, verilerin toplanması ve analizine ilişkin bilgiler verilmiştir.

\subsection{Araştırmanın Modeli}

$\mathrm{Bu}$ çalışmada nitel araştırma desenlerinden durum çalışması kullanılmıştır. Nitel araştırma "gözlem, görüşme ve doküman analizi gibi nitel veri toplama yöntemlerinin kullanıldığı, alg1ların ve olayların doğal ortamda gerçekçi ve bütüncül bir biçimde ortaya konmasına yönelik nitel bir sürecin izlendiği araştırma" türü olarak tanımlanmaktadır (Yıldırım ve Şimşek, 2013: 45). Nitel araştırma modeli karmaşık durumları ortaya koymaya yönelik güçlü bir potansiyelle birlikte zengin ve bütüncül bir içerik sunmaktadır (Miles ve Huberman, 2016: 10). Nitel araştırma yönteminin araştırmalarda tercih edilmesinin nedenlerinden biri duygu, düşünce süreçleri ve hisleri daha iyi anlayabilmek içindir (Ekiz, 2003: 25). Yin'e göre (2014) durum çalısması bir olay ve bağlam arasındaki sınırlar açık olmadığında güncel bir durumu gerçek yaşam alanında irdelemek ile ilgilidir (Akar, 2016: 117). Bu çalışmada, okul müdürlerinin karşılaştıkları sorunları onların algı ve görüşlerine dayalı olarak kendi bağlamında ayrıntılı ve ve bütüncül bir şekilde araştıma amaçlandığından durum çalışması tercih edilmiştir. 


\section{2. Çalışma Grubu}

Araştırmanın çalışma grubu 2016-2017 eğitim-öğretim yllında Diyarbakır il merkezinde yer alan kamu ilkokullarında görevli 20 okul müdüründen oluşmaktadır. Araştırmada amaçlı örnekleme yöntemi ile sosyoekonomik durum açısından farklılık gösteren okullar örnekleme seçilmiştir. Araştırma kapsamında müdürlerin çalıştıkları ilkokullar ziyaret edilerek gönüllülük ilkesine dayalı olarak görüşmeler gerçekleştirilmiştir. Araştırmaya katılan müdürlerin bazı demografik özellikleri şöyledir: Görüşme yapılan müdürlerin tamamı erkektir. Eğitim durumları açısından katılımcı müdürlerin 1'i önlisans, 13'ü lisans ve 6'sı ise yüksek lisans mezunudur. Mesleki kıdem bakımından ise katılımciların 1'i 1-5 y1l, 5'i 6-10 y1l, 6's1 11-15 y1l ve 8'i de 16 yil ve üzeri bir kıdeme sahiptir.

\subsection{Veri Toplama Arac1}

$\mathrm{Bu}$ araştırmanın verileri yarı yapılandırılmış görüşme tekniği kullanılarak toplanmışır. Yarı yapılandırılmış görüşme tekniğinde, araştırmacı önceden hazırladığı konu veya alanlara sadık kalarak hem önceden hazırlanmış soruları sorma hem de bu sorular konusunda daha ayrıntılı bilgi alma amacıyla ek sorular sorma özgürlüğüne sahiptir (Yıldırım ve Şimşek, 2013: 150). Yarı yapılandırılmış görüşme tekniği, diğer görüşme tekniklerine nazaran daha esnek bir yapıya sahip olması sayesinde eğitimbilim araştırmalarına daha uygun bir veri toplama tekniğidir (Türnüklü, 2000: 547). Yarı yapılandırılmış görüşmeler, hem sabit seçenekli cevaplamayı hem de ilgili alanda derinlemesine gidebilmeyi birleştirir (Büyüköztürk, Kılıç-Çakmak, Akgün, Karadeniz ve Demirel, 2008:234).

$\mathrm{Bu}$ araştırmada kullanılan görüşme formu için ilgili literatür taranmış ve yarı yapılandırılmış görüşme taslak formu hazırlanarak alan uzmanlarına inceletilmiştir. Ölçme aracında "Eğitim öğretim sürecinde en sık karşılaştığının sorunlar nelerdir?” şeklinde açık uçlu ve katılımcıların görüşlerini detaylı bir şekilde ifade edebilecekleri bir soru sorulmuştur.

\subsection{Verilerin Toplanmas1}

Araştırma kapsamında veri toplamak için Diyarbakır il merkezindeki ilkokullarda görevli müdürler ile görüşme yapabilmek için okul yöneticileriyle araştırmaya yönelik görüşmelerin yapılması konusunda izlenecek yöntemler görüşülmüştür. Uygun olan zaman belirlendikten sonra okulda birebir görüşmeler yapılmıştır. Görüşmeler esnasında ilgili yerlerde sonda sorular ile görüşmeler detaylandırılmıştır. Görüşme esnasında verilen yanıtlar katılımcılar tarafindan görüşme formlarına kayıt edilmiş̧ir.

\subsection{Verilerin Analizi}

Miles ve Huberman’a (2016: 10,11) göre nitel veri analizi üç bölümde incelenir; verilerin azaltılmas1, verilerin gösterimi ve sonuçları ortaya koyma/doğrulama. "Verinin işlenmesi aşamasında araştırmacı önce veriyi inceler ve kodlar. Veriyi kodlarken araştırma problemine göre önemli olan kavramları ve temaları kullanır. Bu şekilde veri özetlenmiş ve önemli olanlanı seçilmiş olur. Daha sade ve araştırma problemi ile uyumlu hale gelen veri seti ikinci aşamada çeşitli grafikler tablolar ve şekiller yoluyla görsel hale getirilir. Verinin görsel hale getirilmesi gerek ortaya çıkan kavramların ve temaların birbiriyle ilişkilerinin belirgin hale getirilmesi, gerekse bu kavram, tema ve ilişkilerden yola çıkarak bazı sonuçlara ulaşılması yönünden büyük önem taşır. Son aşamada ise ortaya çıkan kavramlar, temalar ve ilişkiler yorumlanır, karşılaştırılır ve teyit edilir. Bu şekilde araştırma sonuçlarının anlamlandırılması ve geçerliğinin sağlanması mümkün olmaktadır” (Yıldırım ve Şimşek, 2013: 255). Bu araştırmada bu aşamalar göz önünde bulundurularak, elde edilen veriler incelenmiş ve kodlanmıştır. Daha sonra tablolaştırılarak görsel hale getirilmiş ve ortaya çıkan kavramlar, temalar ve ilişkiler yorumlanarak çeşitli sonuçlara ulaşılmıştır.

Müdürlerin görüşlerini yansıtmak için onların belirttiği ifadelerden doğrudan alıntılar yapılmıştır. Alıntılar yapılırken katılımcıların isimleri yerine müdür 1 (M1), müdür 2 (M2) vb. şeklinde k1saltılarak kodlama yapılmıştır. Okul müdürlerinin görüşme sorularına verdiği yanıtlar araştırmacılar tarafından ayrı ayrı incelenerek kodlanmış ve gerekli düzenlemeler yapılmıştır.

\subsection{Geçerlik ve Güvenirlik}

Araştırmanın geçerliliği için iki alan uzmanının görüşü esas alınmıştır. Uzman görüşlerine göre araştırmada kullanılan görüşme formu ile toplanan veriler araştırma amaçlarına uygundur. 
Araştırmanın güvenirliği için öncelikle katılımcıların ifadeleri gözden geçirilerek geri bildirim sağlanmışır. Veri analizi sürecindeki güvenirlik için ise iki araştırmacı ayrı ayrı kodlama ve temalandırma yapmışlardır. Görüş birliğine varılan noktalar birleştirilerek temalandırılmış, görüş ayrıllğı olan hususlar tekrar gözden geçirilip düzenlenmiştir. Ayrıca bulgularda katılımcı ifadelerinden doğrudan alıntılar yapılarak güvenirlik artırılmıştır.

\section{BULGULAR}

Bu bölümde elde edilen bulgular içerik analiziyle oluşturulmuş temalar altında tasnif edilerek sunulmuştur. Ayrıca okul müdürlerine eğitim-öğretim sürecinde en sık karşılaştıkları sorunların neler olduğuna yönelik sorulan sorulara verilen cevaplar analiz edilerek tablolaştırılmıştır. Buna göre katılımcı müdürler en sık karşılaştıkları sorunları sırasıyla; (1) okulun fiziki sorunları ( $\mathrm{f}=28)$, (2) yönetim ile ilgili karşılaştıkları sorunlar (f=25), (3) öğretmenler ile ilgili karşılaştıkları sorunlar ( $\mathrm{f}=9$ ), (4) veliler ile ilgili karşılaştıkları sorunlar ( $\mathrm{f}=7$ ) ve (5) öğrenciler ile ilgili karşılaştıkları sorunlar $(\mathrm{f}=4)$ şeklinde ifade etmişlerdir. Bu sorunlar aşă̆ı̆da sırasıyla ele alınmıştır.

\section{1. Müdürlerin Karşılaştıkları Fiziksel Sorunlar}

Araştırmaya katılan okul müdürlerinin eğitim-öğretim sürecinde en sık karşılaştıkları fiziksel sorunlar aşağıda Tablo 1'de verilmiştir.

Tablo 1. Müdürlerin Karşılaştıkları Fiziksel Sorunlar

\begin{tabular}{ll}
\hline Kodlar & $\boldsymbol{f}$ \\
\hline Destek personel yetersizliği & 9 \\
\hline Sınıf mevcutlarının kalabalık oluşu & 7 \\
\hline Fiziki (sosyal/sportif vb) alanlarının yetersizliği & 5 \\
\hline Ders materyali eksiklï̆i/yetersizliği & 3 \\
\hline Temizlik eksikliği & 3 \\
\hline Okulda güvenlik sorunu & 1 \\
\hline Toplam & $\mathbf{2 8}$ \\
\hline Tablo 1'de görüldüğü gibi, araştırmaya katılan okul müdürleri eğitim-öğretim sürecinde en stk
\end{tabular}

Tablo 1'de görüldüğü gibi, araştırmaya katılan okul müdürleri eğitim-öğretim sürecinde en sık karşılaştıkları fiziksel sorunlardan; destek personel yetersizliği $(\mathrm{f}=9)$, sınıf mevcutlarının kalabalık oluşu ( $\mathrm{f}=7$ ), fiziki (sosyal/sportif vb) alanlarının yetersizliği ( $\mathrm{f}=5$ ), ders materyali eksikliği/yetersizliği $(\mathrm{f}=3)$, temizlik eksikliği ( $\mathrm{f}=3$ ) ve okulun güvenliği $(\mathrm{f}=1)$ sorunlarını ifade etmişlerdir. Bu fiziksel sorunlardan en çok ifade edilenler aşağıda sırasıyla ele alınmış olup buna yönelik çözüm önerileri sunulmuştur.

\subsubsection{Destek Personel Yetersizliği ve Buna Yönelik Çözüm Önerileri}

Okul müdürleri karşılaştıkları fiziksel sorunlardan en fazla okullardaki destek personelinin eksikliğini sorun olarak belirtmişlerdir. Bu sorunu okul müdürleri şu şekilde ifade etmişlerdir:

“Okullarda kadrolu hizmetli ve güvenlik görevlilerinin bulunmaması veya yetersiz olması (M8), okullarda yeterince personel olmayış1 (M12, M13, M14), Okullardaki hizmetli personel eksikliği (M18), okul güvenlik ve temizlik personelinin ihtiyacı karşılamaması (M3, M10, M1), teknik personel eksikliğinden dolayı alanımız ve eğitimimiz dışındaki problemlerle uğraşmak durumundayız. Örneğin; okulun tesisat sorunu, elektrik, inşaat vb sorunlar1 (M16)".

Okul müdürleri okullarında destek personelinin yetersizliğinin okulun işleyişine zarar verdiğini ve bu sorunu çözmek için okullara hizmetli ve diğer destek personelinin alınması gerektiği şeklinde çözümler önermektedirler. Bu anlamda müdür görüşlerinden bazıları şöyledir:

“Okullara güvenlik ve personel alımı için hizmet alım bütçesi verilmesi (M3), bu sorunu çözmek için ya devlet personel görevlendirecek ya da okul idaresine personel görevlendirmesi için kaynaklar ayıracak (M5), okulun temizlik ve güvenlik sorunu için kadrolu elemanlara ihtiyaç duyulmaktadır. Çünkü geçici (İşkur vb) görevlendirmelerle gelen elemanlardan verim alınmamaktadır (M8), Bakanlık tarafindan okulun her türlü giderleri için ödenek gönderilmesi (M10), personelin okul müdürü tarafından evi okula yakın olanlardan personel olarak çalıstırılması. Gerek siyasiler gerekse diğer bürokratların müdahale etmemesi, temizlik personelleri hizmet alımı yoluyla çalıstırılması (M12). Eğitim öğretim sürecinde destek personeli (temizlik ve bakım vb) alımı yapılmalı (M14, M13). Okullara teknik personel görevlendirilmeli (M16). Temizlik ve diğeri işler için personel alımı yapılmalı (M18)". 


\subsubsection{Sınıf Mevcutlarının Kalabalık Oluşu ve Buna Yönelik Çözüm Önerileri}

Okul müdürleri okullarında yeterli derslik olmadığından derslik başına düşen öğrenci sayısının fazla oluşunu sorun olarak ifade etmişlerdir. Bu soruna değinen müdürlerin görüşlerinden bazıları şöyledir:

“Okulumuzdaki derslik yetersizliğinden kaynaklanan sınıf mevcutlarının fazlalığı (M18). Okulumuzda eğitim öğretimi etkileyen en önemli sorun sınıf mevcutlarının kalabalık olmas1 (M10). Okullarımızın diğer bir sorunu sınıf mevcutlarının kalabalık olması (M9, M5, M7, M19). Öğrenci mevcutlarının fazlalığı ve bundan dolayı okullardaki laboratuvar ve bilgisayar odalarının sınıfa dönüştürülmesi (M13)”.

Okul müdürleri okullarındaki sınıf başına düşen öğrenci sayısının azaltılması için yeni okulların ve dersliklerin yapılmasını önermektedirler. Bu konudaki müdür görüşlerinden bazıları şunlardır:

"Devlet acilen eğitim eylem planını hazırlamalı ve derslik ihtiyacını giderilmeli (M7), sınıf mevcutlarının düşürülebilmesi için yeni okullarının açılması gerekir (M10). Derslik yapılmalı (M18, M19). Sınıf mevcutlarının düşürülmesi gerekir. Bunun için butik okullar açılmalıdır. Öğrencilerin evlerine yakın butik okullarda eğitim görmesi başarıyı da artıracaktır (M9). İlkokullar birbirine yakın (yaklaşı 1-2 km ara ile) ve küçük olarak yapılmalı (M13). Öğrenci yoğunluğunun azaltılması için derslik veya okullar yapılmalıdır (M5)”.

\subsubsection{Fiziki Alanlarının Yetersizliği ve Buna Yönelik Çözüm Önerileri}

Okul müdürleri, karşılaştıkları fiziksel sorunlardan birisinin okullardaki sosyal, sportif vb fiziki alanların olmayışı ya da yetersiz oluşu şeklinde ifade etmişlerdir. Bu soruna yönelik müdür görüşlerinden bazıları şu şekildedir:

“Okulumuzun en büyük sıkıntısı fiziki koşulların yetersizliği, mesela okul bahçesinin küçük olması, oyun alanlarının olmayışını en önemli sorun olarak görüyorum (M6). Okulun fiziki yapısı uygun değil (M2). Sosyal aktivitelerin ve spor yapılacak alanların olmaması (M4). Okulların fiziki koşullarının yetersiz oluşu (M7). Okulun fiziki eksiklikleri (M15)".

Okul müdürleri okullarında sosyal, sportif vb aktivitelerin yapılacağı alanların öğrenci ihtiyacını karşılayacak şekilde düzenlenmesi gerektiğini ifade etmişlerdir. Bu konuda müdürlerin önerilerinden bazıları şöyledir:

“Okul, uygulamalı eğitime uygun bir şekilde öğrencilerin derse aktif katılımının sağlanabileceği ortamlar olarak düzenlenmelidir (M2). Daha geniş alanlarda okullar yapılmalı. spor salonu ve diğer sosyal etkinlikler için muhakkak alan olmalı, bunların yapımına, okul inşaatının başlamasıyla beraber başlanmalı (M4). Mevcut okul bahçemizin büyütülmesi ve çocuklar için teneffüslerde rahatlatıcı ve eğlendirici oyun alanlarının oluşturulmasıyla okul daha eğlenceli bir yer haline getirilebilir (M6). Fiziki koşullar, sosyal ve kültürel etkinlikler için uygun hale getirilmeli (M7). Okullar mimari açıdan daha kullanışı yapılmalı ayrıca okullara spor salonu ve sanatsal etkinliklerin yapılacağı atölyeler kurulmalı (M15)".

\subsubsection{Diğer Fiziksel Sorunlar ve Bunlara Yönelik Çözüm Önerileri}

Okul müdürlerinin karşılaştıkları diğer fiziksel sorunlar; ders materyali eksikliği/yetersizliği, okulun temizlik ve güvenlik ile ilgili sorunlardır. Okul müdürleri bu sorunları şu şekilde ifade etmişlerdir:

“Okullarımızda yeterli donanım ve teknolojinin olmaması (M4). Okullarımızın araç gereç ihtiyacı (M9, M15). Okulumuzun en büyük sorunu temizlik sorunu (M9, M13). Okullarımızda yeterince personel olmadığından sınıflar tuvalet ve diğer birimler yeterince temizlenemiyor (M12). Okulumuzun sorunlarında biri de güvenlik sorunu. Okul kapılarımızın tüm vatandaşlara, öğrencilere ders saatleri süresince açı olmasından dolayı okullarımıza giren çıkan herkes veli değildir veya iyi niyetli değildir, içeri giren genç, yaşlı, teyze, abla vb art niyetli olabilir. Hırsızlık, istismar, kavga, zarar vermek vb. olumsuz davranışları yapabilir (M9)”.

Okul müdürleri karşılaştıkları bu tür fiziksel sorunların çözümüne ilişkin çeşitli önerilerde bulunmuşlardır. Bu bağlamda bazı müdür görüşleri şöyledir:

“Okullarımızın araç gereç ihtiyacı ödeneklerle giderilebilir (M9). Araç-gereçlerin karşılanması için gerekli ödeneğin okul idarelerine verilmesi ve öğrencilerin ihtiyaçlarına göre idarenin malzeme alması gerekir (M15). Okullarımızın temiz, hijyen ve sağlıklı bir ortamda eğitim öğretim yapabilmeleri için Bakanlığımızca veya Valiliğimizce okullarımızda hizmetli alımı yapılmalıdır (M9). Gerek siyasiler gerekse diğer bürokratların 
müdahale etmeden temizlik personelleri hizmet alımı yoluyla çalıştırılmalı (M12). Temizlik işleri özel sektöre devredilmeli (M13). Okullarımıza güvenlik personeli, bekçi hizmet alımı yapılmalıdır (M9)”.

\subsection{Müdürlerin Yönetim İle İlgili Karşılaştıkları Sorunlar}

Araştırmaya katılan okul müdürlerinin eğitim-öğretim sürecinde yönetim ile ilgili karşılaştıkları sorunlar aşağıda Tablo 2'de verilmiştir.

Tablo 2. Müdürlerin Yönetim İle İlgili Karşılaştıkları Sorunlar

\begin{tabular}{ll}
\hline Kodlar & $\boldsymbol{f}$ \\
\hline Okullara yeterli bütçe verilmemesi & 13 \\
\hline İkili öğretim uygulaması & 5 \\
\hline Yöneticilerin nitelik olarak eksiklikleri/liyakatsizliği & 3 \\
\hline Kısa süreli yönetim politikaları & 1 \\
\hline Atama ve yer değiştirme politikaları & 1 \\
\hline Ö̆ğretmen yetiştirmedeki eksiklikler & 1 \\
\hline Müfredat eksiklikleri & 1 \\
\hline Toplam & $\mathbf{2 5}$ \\
\hline
\end{tabular}

Tablo 2'de görüldüğü gibi, araştırmaya katılan müdürler yönetimle ilgili karşılaştıkları sorunları; okullara yeterli bütçe verilmemesi ( $\mathrm{f}=13)$, ikili öğretim uygulaması (f=5), yöneticilerin nitelik olarak eksiklikleri/liyakatsizliği ( $(\mathrm{f}=3$ ), kısa süreli yönetim politikaları ( $\mathrm{f}=1$ ), atama ve yer değiştirme politikaları ( $\mathrm{f}=1$ ), öğretmen yetiştirmedeki eksiklikler ( $\mathrm{f}=1$ ) ve müfredat eksiklikleri ( $\mathrm{f}=1$ ) şeklinde ifade etmişlerdir. $\mathrm{Bu}$ sorunlardan en çok ifade edilenler sırasıyla açıklanmıştır.

\subsubsection{Okullara Yeterli Bütçe Verilmemesi ve Buna Yönelik Çözüm Önerileri}

Katılımcı okul müdürleri karşılaştıkları yönetimsel sorunlardan en fazla okullara yeterli bütçe verilmeyişini ifade etmişlerdir. Bu sorunu ifade eden müdür görüşlerinden bazıları şu şekildedir:

“Okulumuzun herhangi bir ödeneğinin olmaması büyük engel teşkil ediyor (M16). Okulların fiziki ihtiyaçlarını karşılayacak bütçesinin olmaması (M3, M5). Ödenek sorunu (M1, M4, M10). Eğitim öğretim faaliyetlerini karşılamak ve kalitesini artırmak için yatırımın azlığı (M3). Okulların bakım- onarım tamiri için okul ödeneğinin bulunmaması (M8). Öncelikle ilkokullarda ödenek olmadığı için yapılmak istenen çalışmalar tam anlamıyla yapılamıyor (M11). Yeterince ödenek olmayışı. Velilerden alınan bağışlarla okullar idare edilmemektedir. Veli profili iyi olan okullar bu ihtiyaçları az da olsa gidebiliyor, diğer okullar gerek temizlik gerekse diğer işlerin yapilmasında çok büyük sıkıntılar içerisindeler (M12). Okullar ekonomik sorunlarla uğraşıyor, öğretmen idareciler ve okul aile birliği çok sıkıntı yaşıyor (M13). Okuldaki ödenek eksikliği (M14, M18)".

Okul müdürleri okullarındaki ihtiyaçları karşılayabilmek için okullara ödenek verilmesi gerektiğini ve bu ödeneklerin kullanımının okul müdürünün yetkisinde olması gerektiği yönünde çeşitli çözüm önerileri sunmuşlarıdır. Bu konudaki müdür görüşlerinden bazıları şu şekildedir:

“Özellikle ilkokul ve ortaokullarda okul idaresinin kullanabileceği bir ödeneğin olması gerekmektedir. Okul idaresi bu ödenekle hizmet ve mal alımı yapabilmelidir (M1). Okullara, onarım ve yenileme için bütçe verilmeli (M3, M5). Eğitim öğretim ödeneklerinin okullara verilmeli (M3, M18). Bakanlık düzeyinde okullarda harcanmak üzere ya okula ya da ilçe milli eğitim müdürlüklerine makul düzeyde ödenek aktarılması. Okullar ihtiyacı olduğu anda küçük veya büyük çaplı onarımlarını yapabilmelidir. (M8). Bakanlık tarafından okulun her türlü giderleri için ödenek gönderilmeli (M10, M4). Bakanlığın başlatmış olduğu ödenek programının direk okul müdürünün kullanımına açılması hem okulların eğitim öğretim faaliyetlerinin amacına uygun, hızlı bir şekilde yürütülmesine hem de okullardaki israfi önleyecektir (M11). Kapı pencere sıra masa ve diğer donatım tesisat işleri için Bakanlık tarafindan okullara bütçe ayrılması ve bu bütçenin de okul müdürlerince kullanma yetkisi verilmesi gerekir (M12). İlkokullara ödenek ayrilmas1, ücretsiz dağ1tılan kitapların cüzi bir ücretle öğrencilere dağıtılması (M13). MEB bünyesinde bulunan resmi eğitim kurumlarında belli bir kritere göre (derslik sayıs1, öğrenci ve personel sayısı vb) ödenek ayrılarak, okulun ihtiyaç duyacağı hizmet ve mal alımlarının gecikmeye mahal verilmeden karşılanması eğitimde kaliteyi artıracaktır (M14)”. 


\subsection{2. İkili Öğretim Uygulaması ve Buna Yönelik Çözüm Önerileri}

Okul müdürlerinin karşılaştıkları diğer yönetsel sorunlardan biri de okullardaki ikili öğretim uygulamasıdır. Bu uygulamanın okullarda nasıl sorun oluşturduğuna yönelik müdür görüşlerinden bazıları şöyledir:

“Okulumuzda eğitim öğretimi etkileyen en önemli sorun ikili öğretimdir (M10). Okulların ikili eğitim yapması (M11, M7). Okulumuzun en önemli problemlerinden birisi ikili öğretimdir. Çok erken okula gelmek zorunda kalan öğrenciler ve çok geç giden öğrenciler sorun oluşturuyor (M20). Eğitimde (ikili öğretim uygulamasında özellikle kış aylarında öğrenci ve öğretmenlerin çok erken saatlerde okula gelmek zorunda kalmaları eğitim öğretimi olumsuz etkilemektedir (M8)".

Okul müdürleri ikili öğretim uygulamasından kaynaklanan sorunları çözmek için bu uygulamanın kaldırılması gerektiğini ifade etmişlerdir. Bu bağlamda müdür görüşlerinden bazıları şunlardır:

"Eğitimin öncelikle tam güne yayılması gerekir (M10). Normal öğretime geçilmesi bunun için de okul ve derslik sayılarının artırılması gerekmektedir (M8). Okul sabah - öğlen devreleri şeklinde olmalı (M7). Tüm bölgelerde öğrenci sayısına göre yeni okul ve derslikler yapılmalı (M11). Yeni okul ve derslikler inşa edilerek bu sorun bir an önce çözülmeli (M20)".

\subsubsection{Yöneticilerin Eksiklikleri/Liyakatsizliği ve Buna Yönelik Çözüm Önerileri}

Okul müdürlerinin karşılaştıkları sorunlardan biri de okul yöneticilerinin eksiklikleri ve liyakatsizliğidir. Yöneticiler ile ilgili bu sorunu ifade eden müdürler şu şekilde fikir beyan etmişlerdir:

“Okul idarecilerinin tecrübesiz olması (M1). Yönetimdeki eksikliklerimiz, okulu kontrol altında tutamayışımız (M2). Yöneticilere hizmet içi eğitimi verilmemesi büyük sorun. Çünkü kendimizi güncelleme şansımız olmuyor (M16)".

Okul müdürleri yöneticilerin bu eksikliklerini gidermeleri için çeşitli önerilerini şu şekilde ifade etmişlerdir:

“Okul idarecisi seçiminde liyakate göre karar verilmeli. Sözlü sınavlarla yapılan keyfi muamelenin önüne geçilmeli (M1). Okul müdür yardımcılarının eğitimci işletmeci, kamu yönetimi, sosyoloji gibi alanlarda bir kaç kişi olması gerekir (M2). Yöneticilere üniversiteden akademisyenler tarafindan seminer ve kurslar verilebilir (M16)".

\subsubsection{Yönetim İle İlgili Karşılaş1lan Diğer Sorunlar ve Bunlara Yönelik Çözüm Önerileri}

Okul müdürlerinin karşılaştıkları diğer yönetimsel sorunlar; kısa süreli yönetim politikaları, atama ve yer değiştirme politikaları, öğretmen yetiştirmedeki eksiklikler ve müfredattaki eksikliklerdir. Okul müdürleri bu sorunları şu şekilde ifade etmişlerdir:

"Milli Eğitim Bakanlarının çok sık değişmesi ve her gelen bakanın kendi politikalarını hayata geçirmek istemesi (M4). Öğretmen rotasyonlarının yapılmaması (M1). Öğretmen yetiştiren üniversitelerin kalitesiz oluşu. Ülkemizdeki üniversitelerinin çoğunun fiziki koşulları yetersiz ve akademik kadrolarının yeterli olmaması (M7). Müfredatın öğrencilerin ihtiyaç, beceri ve beklentilerini karşılayamaması (M15)”.

Bu sorunların çözümüne yönelik okul müdürlerinin ortaya koyduğu öneriler şu şekildedir:

“Bakanlığın kendine özgü bir politikası olmalı, eğitimin kendi politikası olmalı. Bakanlar değişse bile, eğitimde politikalar değişmemeli, yani eğitimde hükümet değil, devlet politikası olmalı (M4). MEB rotasyon uygulamasını bir an önce ve adil bir biçimde yapmalı (M1). Üniversitelerin fiziki koşulları düzeltilmeli ve bilimsel çalışmalara yeteri kadar bütçe ayrılmalı, bütçe etkin ve verimli kullanılmalı, eğitim fakültelerinin akademik kadrolanı her türlü siyasi ve ideolojik davranışlardan uzak bilimsel çalışmaya önem veren akademisyenlerce yapılmalı, akademisyen donanımlı olmalı ki kaliteli öğretmen yetiştirilsin (M7). Müfredat sadeleştirilmeli ve her birey farklıdır ilkesinden yola çıkarak öğrencilerin bilişsel seviyesine uygun müfredat hazırlanmalı (M15)".

\subsection{Müdürlerin Öğretmenler İle İlgili Karşılaştıkları Sorunlar}

Araştırmaya katılan okul müdürlerinin eğitim-öğretim sürecinde öğretmenler ile ilgili karşılaştıkları sorunlar aşağıda Tablo 3'de verilmiştir. 
Tablo 3. Müdürlerin Öğretmenler İle İlgili Karşılaştıkları Sorunlar

\begin{tabular}{ll}
\hline Kodlar & $\boldsymbol{f}$ \\
\hline Ö̆̆retmenlerin mesleki yetersizliği & 8 \\
\hline Öğretmenlerin ekonomik yetersizlikleri & 1 \\
\hline Toplam & $\mathbf{9}$ \\
\hline
\end{tabular}

Tablo 3'de görüldügüü gibi, araştırmaya katılan okul müdürleri öğretmenler ile ilgili karş1laştıkları sorunları; öğretmenlerin mesleki yetersizliği $(\mathrm{f}=8)$ ve öğretmenlerin ekonomik yetersizlikleri ( $\mathrm{f}=1)$ şeklinde ifade etmişlerdir. Bu sorunlar sırasıyla açıklanmıştır.

\subsection{1. Öğretmenlerin Mesleki Yetersizliği ve Buna Yönelik Çözüm Önerileri}

Okul müdürleri okullarındaki öğretmeler ile ilgili olarak en sık karşılaştıkları sorunu öğretmenlerin mesleki açıdan yetersizlikleri olarak ifade etmişlerdir. Bu sorunu ifade eden müdür görüşlerinden bazıları şöyledir:

“Öğretmenin kalitesi, öğretmenin mesleki ve sosyal kültürel anlaminda yetersiz oluşu (M7). Öğretmenlerin mesleki yeterliliklerinin eksikliği, özellikle son yıllarda mezun olan öğretmenler pedagojik formasyon konusunda çok yetersizdir. Sınıfta sınıf yönetimi, öğrenciye sahip çıkma ve öğrencilerin seviyesine inme konusunda çok büyük sıkıntılar yaşanmaktadır (M12). Öğretmenlerin yetersizliği ve derslerde isteksiz oluşu (M2). Öğretmenlerimizin kendilerini mesleki ve kişisel açıdan geliştirmemeleri (M9). Mevcut öğretmenlerin eksiklikleri (M7). Öğretmenlerin mesleki yetersizliği (M15). Öğretmenlerin maddi kaygılarından dolayı kendilerini eğitime tam olarak odaklayamamaları (M4)”.

Okul müdürleri öğretmenlerin mesleki açıdan eksikliklerini gidermeleri için çeşitli öneriler öne sürmüşlerdir. Bu bağlamda ortaya konulan önerilerden bazıları şöyledir:

“Öğretmenler değişen programa göre sürekli hizmet içi eğitime tabi tutulmalı (M2). Öğretmenler planlı ve etkin bir hizmet içi eğitime alınmalı (M7). Öğretmenlerimiz öğrencilerin ihtiyaçlarına cevap verebilmeleri için kendilerini hem mesleki açıdan hem de kişisel açıdan geliştirmelidir (M9, M6). Üniversiteye giriş sınavlarında öğretmen adaylarının akademik olarak çok iyi bir dilime girmesi gerekir, öğretmen adayları, akademik başarının yanında adil ve kapsamlı bir müfredattan geçmeli, sosyal anlamda kendini ifade edebilen insan ilişkileri iyi, empati kurabilen ve öğrenci seviyesine inebilen adaylar arasından seçilmeli (M7). Eğitim fakültelerinde pedagojik formasyon konularına daha çok ağırlı verilmeli, stajyerlik süresince öğretmenler ciddi denetlenmeli, mutlaka sınıfta denetlenmeli. Ayrıca öğretmenlik mesleğini seçenlerin ön sözlü sınava alınması gerekir (M12). Öğretmen adayları üniversite eğitiminde teorik bilgiye paralel olarak uygulama eğitimlerini de yeterince almaları gerekir. Mevcut öğretmenler ise profesyonel kişilerce hizmet içi eğitime alınmalı (M15)”.

\subsection{2. Öğretmenlerin Ekonomik Sorunları ve Buna Yönelik Çözüm Önerileri}

Okul müdürlerinin öğretmenler ile karşılaştıklanı diğer bir sorun öğretmenlerin yaşadıkları ekonomik sorunlardır. Bu sorunu müdürler şöyle ifade etmişlerdir:

Öğretmenler maddi kaygılarından dolayı kendilerini eğitime tam olarak veremiyor, eğitim dişında birçok problemle uğraşmak zorunda kaliyorlar (M4).

Bu konuda öneri geliştiren okul müdürünün ifadeleri şöyledir:

Öncelikle öğretmen derse girdiğinde, maddi kaygıları olmadan sadece dersi düşünerek kendini eğitime hazırlamalıdır. Yani öğretmenlerin maaşları artırılmalı ve toplumun gözündeki itibarları artırılmalıdır (M4).

\subsection{Müdürlerin Veliler İle İlgili Karşılaştıkları Sorunlar}

Araştırmaya katılan okul müdürlerinin eğitim-öğretim sürecinde veliler ile ilgili karşılaştıkları sorunlar aşağıda Tablo 4'de verilmiştir.

Tablo 4. Müdürlerin Veliler İle İlgili Karşılaştıkları Sorunlar

\begin{tabular}{ll}
\hline Kodlar & $\boldsymbol{f}$ \\
\hline Velilerin ilgisizliği & 6 \\
\hline Velilerin yanlış tutum ve davranışları & 1 \\
\hline Toplam & 7 \\
\hline
\end{tabular}

Tablo 4'de görüldüğü gibi, araştırmaya katılan müdürler veliler ile ilgili karşılaştıkları sorunları; velilerin ilgisizliği ( $\mathrm{f}=6$ ) ve velilerin yanlış tutum ve davranışları $(\mathrm{f}=1)$ şeklinde ifade etmişlerdir. Bu sorunlar sırasıyla açıklanmıştır.

\subsubsection{Velilerin İlgisizliği ve Buna Yönelik Çözüm Önerileri}

Okul müdürleri velilerle ilgili olarak en çok velilerin okula ve eğitim öğretime yönelik ilgisizliklerini sorun olarak ifade etmişlerdir. Bu sorunu ifade eden müdür görüşleri şöyledir: 
"Velinin okula karşı ilgisinin yetersizliği başta gelen sorunlarımızdır (M5). Velilerin eğitim ve öğretimdeki duyarsızlığı (M10). Velilerin yeterince bilinçli olmaması (M11). Velilerin ilgisizliği (M17). Öğrenci velileri okula ilgisizdirler (M19). Veliler okul faaliyetlerine yeterince katılmıor (M20)”.

Okul müdürleri velilerin okula katılımını arttırmak için çeşitli öneriler ileri sürmüşlerdir. Bu sorunu çözmeye yönelik müdür önerileri şöyledir:

"Velinin okula karşı ilgisinin artırılması için okulu cazibeli hale getirmek ve velileri eğitmekle olur (M5). Velilere yönelik ilgili eğitim kursları açılmalı (M10). Tüm okullarda veli eğitim seminerleri düzenlenerek farkındalı̆̆ın artırılması sağlanmalı (M11). Veli ziyaretlerine önem verilmeli (M17). Velilere yönelik bilgilendirme çalışmaları yapılmalı (M19). Velilere yönelik daha ciddi bilinçlendirme seminerleri düzenlenmeli (M20)".

\subsubsection{Velilerin Yanlış Tutum ve Davranışları ve Buna Yönelik Çözüm Önerileri}

Okul müdürleri velilerin eğitim sürecine yönelik yanlış tutum ve davranışlarını şöyle ifade etmişlerdir:

"Veliler eğitim ve öğretimdeki her şeye gereksiz bir şekilde karışıyorlar (M10)".

Bu sorunu çözmeye yönelik öneri ifade eden müdür görüşü şöyledir:

"Velilere yönelik ilgili eğitim kursları açılmalı (M10)".

\subsection{Müdürlerin Öğrenciler İle İlgili Karşılaştıkları Sorunlar}

Araştırmaya katılan okul müdürlerinin eğitim-öğretim sürecinde öğrenciler ile ilgili karşılaştıkları sorunlar aşağıda Tablo 5'de verilmiştir.

Tablo 5. Müdürlerin Öğrenciler İle İlgili Karșılaștıkları Sorunlar

\begin{tabular}{ll}
\hline Kodlar & $\boldsymbol{f}$ \\
\hline Öğrencilerin akademik yetersizlikleri & 3 \\
\hline Öğrencilerin hedeflerinin olmaması & 1 \\
\hline Toplam & 4 \\
\hline
\end{tabular}

Tablo 5’de görüldüğü gibi, araştırmaya katılan müdürler öğrenciler ile ilgili karşılaştıkları sorunları; öğrencilerin akademik yetersizlikleri ( $f=3$ ) ve öğrencilerin belli bir hedeflerinin olmaması ( $f=1$ ) şeklinde ifade etmişlerdir. Bu sorunlar sırasıyla açılklanmıştır.

\subsection{1. Öğrencilerin Akademik Yetersizlikleri ve Buna Yönelik Çözüm Önerileri}

Okul müdürleri öğrenciler ile ilgili en sık karşılaştıkları sorun olarak öğrencilerin akademik yetersizliklerini ifade etmişlerdir. Bu sorunu ifade eden müdür görüşleri şöyledir:

“Okulöncesi ve birinci sınıftaki öğrenciler okuduğunu anlamıyor (M17). Temel işlem becerileri ve dil gelişimi sorunu (M17). Öğrencilerin başarıları düşük, ders çalışmıyorlar (M19)”.

Bu sorunu çözmeye yönelik görüş ifade eden müdürlerin önerileri şöyledir:

“Okulöncesi ve birinci sınıflardaki öğrencilere okuduğunu anlamaya yönelik daha hassasiyet gösterilerek eğitim verilmeli (M17). Pratikte işlem gerektiren durumlarla matematik sevdirilmeli ve kelime ezberi ile dil gelişimi sağlamalı (M17). Öğrenciler ders dışı etüt ve ödevlerle desteklenmeli (M19)”.

\subsection{2. Öğrencilerin Hedeflerinin Olmaması ve Buna Yönelik Çözüm Önerileri}

Okul müdürleri öğrencilerin hedeflerinin olmayışını da sorun olarak ifade etmişlerdir. Bu sorunu ifade eden müdür görüşü şöyledir:

“Öğrencilerin belirli bir hedefleri yok (M17)".

Öğrencilerin bu sorununa çözüm ileri süren müdür görüşü şöyledir:

"Öğrenciler motive edilerek öğrencilere hedef saptanmalı (Ö17)".

\section{TARTIŞMA ve SONUÇ}

Diyarbakır il merkezindeki ilkokullarda görevli okul müdürlerinin görüşlerine dayalı olarak eğitim-öğretim sürecinde en sık karşılaşılan sorunlar ve bu sorunların çözümüne ilişkin önerilerin neler olduğunu ortaya çıkartmak amacıyla gerçekleştirilen bu araştırmada önemli bazı sonuçlar elde edilmiştir. Bu bağlamda, okul müdürlerinin görüşlerine göre eğitim-öğretim sürecinde en sık karşılaşılan sorunlar sırasıyla; okulun fiziki sorunları, yönetim ile ilgili karşılaşılan sorunlar, öğretmenler ile ilgili karşılaşılan sorunlar, veliler ile ilgili karşılaşılan sorunlar ve öğrenciler ile ilgili karşılaşılan sorunlardır. 
Okul müdürlerinin eğitim öğretim sürecinde en sık karşılaştıkları fiziksel sorunlar; okullardaki destek personel yetersizliği, sınıf mevcutlarının kalabalık oluşu, fiziki (sosyal/sportif vb) alanlarının yetersizliği, ders materyali eksikliği/yetersizliği, temizlik eksikliği ve okulun güvenliği ile ilgili sorunlardır. Bu bulgulara paralel olarak Aslanargun ve Bozkurt, (2012. 349) diğer sorunlara kıyaslandığında okullardaki fiziksel sorunlarla daha fazla karşılaşıldığını ortaya koymuşlardır. Dağlı ve Han (2017) tarafindan Diyarbakır ilinde yapılan bir araştırmada da öğretmen görüşlerine göre de en sık karşılaşılan sorunlar okulun fiziksel sorunlarıdır. Güneş ve Kara (2016: 149) okullarda fiziki olanaklar ve destek hizmetleri ile ilgili sorunların devam ettiğini ortaya koymuşlardır. Demirtaş, Üstüner ve Özer, (2007: 444) araştırmalarında, ilköğretim okulu yöneticilerinin okullarının fiziksel koşullarını sorun kaynağı olarak değerlendirdiklerini ortaya koymuşlardır. Yılmaz ve Altınkurt, (2011: 953) okulların fiziki yetersizlikleri ve donanım eksikliklerini eğitim sisteminin önemli sorunları olarak ortaya koymuşlardır. Aydın (2000: 3), okullardaki; derslik, bahçe, salon, sahne, kitaplık, laboratuar, işlik gibi tesisler; yapı, donatım ve fiziki koşullar açısından önemli eksiklikler taşıdığını ifade etmiştir. Taşdan, Tösten, Bulut ve Karakaya (2013: 103) tarafindan yapılan bir araştırmada da, okul binalarından kaynaklanan en önemli sorun "okuldaki laboratuarların (örneğin fen, bilgisayar laboratuarı) yetersiz olması" olarak tespit edilmiştir. Adıgüzel, (2009: 92) sınıfların aşırı kalabalık olmasının öğretme-öğrenme süreçlerinde çeşitli sorunlara yol açtı̆̆ını ifade etmektedir. Yılmaz ve Altınkurt, (2011: 951) yaptıkları araştırmada sınıf mevcutlarının kalabalık olmasını önemli bir sorun kaynağ1 olarak tespit etmişlerdir. Tösten, Han ve Ergül, (2016: 443) tarafindan yapılan araştırmada, kamu okullarında okul binasından kaynaklanan sorunların olduğunu ve okulda kullanılabilecek öğretim materyallerinin yetersiz olduğunu ortaya koymuşlardır. Aküzüm, (2017: 167) kurucu okul müdürleriyle yaptı̆̆ı araştırmasında yeni yapılan okullarda okulun bina ve altyapısından kaynaklanan sorunların olduğunu ortaya koymuştur. Ayrıca, Taşdan, Tösten, Bulut ve Karakaya (2013: 103) ve Tösten, Han ve Ergül, (2016: 440) araştırmalarında merkezde hazırlanan programların yerel ihtiyaçlara cevap vermemesi ve ders kitaplarının içerik bakımından yetersiz olmasını önemli sorunlar olarak tespit etmişlerdir. Gedikoğlu'na göre (2005: 72) ilköğretimde finansman yetersizliklerinin yanı sıra, bina ve tesis eksiklikleri ve çok ciddi araç-gereç, laboratuvar donanımı, bilgisayar ve kütüphane yetersizlikleri vardır. Taş, (2010: 87) sınıftaki donanım yetersizliğinin zaman kaybına neden olduğunu ortaya koymuştur. Alanyazındaki bu bulgular bu araştırma sonuçlarıyla paralellik göstermekte ve okullarda fiziksel sorunların hala devam ettiğini ve çözülmesi gereken önemli bir eğitimsel sorun olduğunu ortaya koymaktadır. Bu soruna çözüm olarak, okulların fiziki altyapısının eğitim öğretime hazır hale getirilmesi için okullarda sosyal ve sportif alanlar öğrenci ihtiyaçlarını karşılayacak şekilde düzenlenmeli, okullarda yeterli sayıda ve büyüklükte derslikler yapılarak sinıf mevcutları makul seviyeye çekilmeli, okullarda ders materyali eksiklikleri giderilmeli ve materyal içerikleri öğrenci ihtiyacına göre düzenlenmeli, okulda yeterli sayıda personel istihdam edilip okulun temizlik, güvenlik vb. sorunları çözülmelidir.

Okul müdürlerinin yönetimle ilgili en sık karşılaştıkları sorunlar; okullara yeterli bütçe verilmemesi, ikili öğretim uygulaması, yöneticilerin eksiklikleri/liyakatsizliği, kısa süreli yönetim politikaları, atama ve yer değiştirme politikaları, öğretmen yetiştirmedeki eksiklikler ve müfredat eksiklikleri şeklinde ifade edilmiştir. Alanyazındaki araştırmalar da bu çalışmanın sonuçlarına benzer şekilde sorunlar ortaya koymaktadır. Diyarbakır ilinde Dağlı ve Han (2017) tarafından yapılan araştırmada öğretmenler de benzer şekilde eğitim sisteminin uzun vadeli planlamalardan yoksun olması, sık sık müfredatın değişmesi gibi MEB'in yanlış politikaları, okullara yeterli bütçe verilmemesi ve ikili öğretim uygulaması gibi sorunları en sık karşılaşılan yönetimsel sorunlar olarak ortaya 
koymuşlardır. Çınkır, (2010: 1033) okulların özerk bir bütçesinin olmaması ve okul müdürü atamalarında liyakat ilkelerine uyulmamasını önemli yönetimsel sorunlar olarak belirtmiştir. Aküzüm, (2017: 171) tarafindan yapılan araştırmaya katılan kurucu müdürleri mal ve hizmet alımına ilişkin yapılan harcamaların okulun ihtiyaçlarını karşılamada ve hizmet üretmede karşılaşılan önemli bir sorun olduğunu ifade etmişlerdir. Demir ve Arı (2013: 107) sık değişen programlar ve mevzuatların eğitimdeki en önemli sorunlardan olduğunu tespit etmişlerdir. Aydın, (2000: 3) okulların bir kısmında ikili öğretim yapılmasının okullar açısından önemli bir eksiklik olduğunu ifade etmektedir. Gedikoğlu’na göre (2005: 72) ülkemizde hızlı nüfus artışının yanı sıra, çeşitli nedenlerden kırsal kesimden kentlere doğru göç sonucunda ikili öğretim uygulaması başlatılmıştır. Bu tür yönetimsel sorunlara çözüm olarak, Özellikle ilk ve ortaokullara okul yönetimi tarafindan kullanılacak bütçe tahsis edilmesi gerekir. Okullarda ikili öğretim uygulamasından vazgeçilmeli bunun içinde gerekli alt yap1 çalışmaları yapılmalıdır. Eğitim politikalarımız milli olmalı ve eğitimde uzun vadeli planlamalar yapılmalıdır. Öğretmen ve okul yöneticisi seçme kriterleri adil ve uygun olmalıdır. Ayrıca mevcut öğretmen ve okul müdürlerinin mesleki yeterliklerini artıracak hizmet içi eğitimlere önem verilmelidir. Okul müdürlerinin öğretmenler ile ilgili karşılaştıkları sorunlar; öğretmenlerin mesleki yetersizliği ve öğretmenlerin ekonomik yetersizlikleri şeklindedir. Taşdan, Tösten, Bulut ve Karakaya (2013: 101) tarafından yapılan araştırmada okul yöneticilerine göre öğretmenlerden kaynaklanan en önemli sorunlar öğretmenlerin "kendilerini geliştirmede isteksiz olmaları" ve "okul ihtiyaçları için gerekli mali destek alamamaları” olarak belirlenmiştir. Demir ve Arı (2013: 107) öğretmenler için en rahatsız edici sorunları "gelirin düşük olması" olarak ortaya koymuşlardır. Tösten, Han ve Ergül, (2016: 441) tarafindan yapılan araştırmada öğretmenlerden kaynaklanan en önemli sorun öğretmenlerin kendilerini geliştirmede isteksiz olmalarıdır. Dağlı ve Han’ın (2017) Diyarbakır ilinde öğretmen görüşlerine dayalı yaptıkları araştırmada öğretmenlerin kendilerini geliştirmede isteksiz oluşlarını sorun kaynağı olarak tespit etmişlerdir. Yılmaz ve Altınkurt'a (2011: 953) göre öğretmen niteliğinin düşüklüğü eğitim sisteminin önemli sorunları arasındadır. Çınkır, (2010: 1033) öğretmen performanslarının düşük olmasını önemli bir sorun olarak belirtmiştir. Aslanargun ve Bozkurt’a göre (2012: 351) öğretmenler hizmet sundukları öğrenci ve velilerin değişen beklentilerine cevap verebilmek ve güncel bilgilerin 1şığında bireysel gelişimlerini sürdürebilmek için yeni bir takım roller üstlenmek durumundadır. Özan ve Kaya’ya (2009: 111) göre, öğretmenlerin kendilerini geliştirebilmelerini özendirecek ödül sistemi oluşturulmalı ve mesleğinde başarılı öğretmenler mutlaka ödüllendirilmelidir. Öğretmenler ile ilgili ulaşılan sorunlar alanyazında öne çıkan sorunlar ile paralellik göstermektedir. Öğretmenlerin bu sorunlarına çözüm olarak, öğretmenlerin ekonomik durumları ve sosyal statüleri iyileştirilmeli, öğretmenlerin mesleki gelişimlerini sağlamak için destek sunulmalı ve okuldaki gereksiz iş yükünün azaltılması gerekmektedir.

Okul müdürlerinin veliler ile ilgili karşılaştıkları sorunlar; velilerin ilgisizliği ve velilerin yanlış tutum ve davranışlarıdır. Dağlı ve Han (2017) tarafından Diyarbakır ilinde yapılan araştırmada velilerin ilgisizliği öğretmenler tarafından önemli sorunlardan biri olarak ifade edilmiştir. Çınkır, (2010: 1033) velilerin eğitime ve okula karşı ilgisizliği ve eğitime destek konusunda isteksizliğini önemli sorunlar olarak ortaya koymuştur. Adigüzel, (2009: 92) ailelere çocuklarına destek olma noktasında görev ve sorumluluğun verilmesi durumunda ailelerin çeşitli şikâyetlerde bulunduklarını ifade etmiştir. $\mathrm{Bu}$ durum velilerin eğitim-öğretime karşı yeterli derecede ilgili olmadıklarını göstermektedir. Taşdan, Tösten, Bulut ve Karakaya (2013: 103) “öğrencilerin ailelerinden yeterli ilgi görmemelerini” velilerden kaynaklanan en önemli sorunlardan olduğunu ortaya koymuşlardır. Tösten, Han ve Ergül, (2016: 440) ailelerin okula yeteri kadar ilgi göstermemelerini, velilerin 
öğretmenlerin işine yersiz karışmalarını ve velilerin öğrenci başarı durumlarının değerlendirilmesine müdahale etmek istemelerini velilerle ilgili önemli sorunlar olarak ortaya koymuşlardır. Demirbulak'ın (2000: 3) yaptığ1 çalışmada elde edilen bulgular veli-öğretmen görüşmelerinin sağlıklı ve işlevsel olmadığ1 yönündedir. Aküzüm (2017: 176) aile katılımının sağlanmasında ve okul-aile birliklerinin öğrenci sorunlarına yönelik etkin olmalarını sağlamada müdürlere önemli görevler düştüğünü ifade etmektedir. Bu araştırma sonuçları alanyazındaki araştırma sonuçlarına paralel olarak velilerin eğitim öğretim sürecinde çeşitli sorunlara kaynaklık ettiklerini göstermektedir. Bu sorunun çözümü için aileleri bilinçlendirmek amacıyla eğitim-öğretim konusunda velilere yönelik seminer ve konferanslar verilebilir.

Okul müdürleri öğrenciler ile ilgili karşılaştıkları sorunları; öğrencilerin akademik yetersizlikleri ve öğrencilerin hedeflerinin olmaması şeklinde ifade etmişlerdir. Güneş ve Kara’ya göre (2016: 149) öğrenciler ile ilgili sorunlardan biri akademik başarı ile ilgili sorunlardır ve bu konuda en fazla dile getirilen sorun ise kitap okuma oranının düşüklügüdür. Dağlı ve Han (2017) tarafindan Diyarbakır ilinde bir yapılan bir araştırmada öğretmenler öğrencilerin akademik yetersizliklerini önemli bir sorun olarak ifade etmişlerdir. Taşdan, Tösten, Bulut ve Karakaya (2013: 101) tarafindan yapılan araştırmada okul yöneticilerine göre öğrencilerden kaynaklanan en önemli sorun öğrencilerin “televizyondaki olumsuz karakterleri benimsemeleri” gibi sorun davranışlar sergilemeleridir. Tösten, Han ve Ergül (2016: 440) tarafından yapılan araştırmada, kamu okullarında öğrencilerden kaynaklanan en önemli üç sorun sırasıyla öğrencilerin televizyondaki olumsuz karakterleri benimsemeleri, akranlarına karşı şiddete başvurmaları ve okul çıkışlarında tehditlere maruz kalmaları gibi sorun davranışlardır. Aydın’a göre (2000: 4) de Türk Eğitim sisteminde öğrencilerle ilgili önemli sorunlarından biri eğitimde rehberlik hizmetlerinin yetersizliğidir. Bu araştırma bulguları da benzer şekilde öğrenci sorunlarını ortaya koymaktadır. Bu sorunlara çözüm olarak, çeşitli seminerler ve rehberlik servisleri aracılığıyla öğrenciler yönlendirilmeli, akademik açıdan eksiği olan öğrencilere yönelik akademik destek sağlanmalı ve öğrencilere yeterli sosyal faaliyetler sunulmalıdır.

\section{KAYNAKÇA}

Adıgüzel, A. (2009). Yenilenen ilköğretim programının uygulanması sürecinde karşılaşılan sorunlar. Mehmet Akif Ersoy Üniversitesi Eğitim Fakültesi Dergisi, (17). 77- 94.

Akar, H. (2016). Durum çalışması. Eğitimde Nitel Araştırma Desenleri (Ed: Ahmet Saban ve Ali Ersoy). Ankara: Anı Yayıncilık.

Aküzüm, C. (2017). Kurucu müdürlerinin okul yönetimi bağlamında karşılaştıkları temel yönetsel sorunlar ve çözüm önerileri. Elektronik Sosyal Bilimler Dergisi, 16 (60), 161-185.

Anderson, M. E. (1991). Principals: How to train, recruit, select, induct and evaluate leaders for America's schools. Eric Clearing House on Educational Management. College of Education. University of Oregon.

Aslanargun, E., ve Bozkurt, S. (2012). Okul müdürlerinin okul yönetiminde karş1laştı̆ğ sorunlar. Gạ̊iantep Üniversitesi Sosyal Bilimler Enstitüsü Dergisi, 11 (2), 349-368.

Aydın, A. (2000). Zorunlu temel eğitim uygulaması ve çözüm bekleyen sorunlar. Pamukkale Üniversitesi Ë̆itim Fakültesi Dergisi. (8), 98 - 103

Aytaç, T. (2002). Post-modern eğitim yöneticisi. 21. Yüsynl Eğitim Yöneticilerinin Yetişmesi Sempozyumu Bildiriler (16-17 Mayıs). Ankara Üniversitesi Eğitim Bilimleri Fakültesi Yayınları No: 191.

Büyüköztürk, Ş., Kılıç-Çakmak, E., Akgün, Ö. E. Karadeniz, Ş. ve Demirel, F. (2008). Bilimsel Araștırma Yöntemleri. Pegem Akademi Yayıncilik.

Campos, R. L, Gomez, R. R. \& Shen, J. (2005). Secondary principals' educational attainment, experience, and professional development in the USA. Int. J. Leadership in Education, 8(4), 309319.

Çınkır, Ş. (2010). İlköğretim okulu müdürlerinin sorunları: Sorun kaynakları ve destek stratejileri. İlkögretim Online, 9 (3), 1027-1036. 
Dağlı, A. ve Han, B. (2017 baskıda). Öğretmen görüşlerine göre Diyarbakır ili eğitim sorunları ve çözüm önerileri. Electronic Journal of Education, 6 (10).

Demir, M. K. ve Arı, E. (2013). Öğretmen sorunları-Çanakkale İli örneği. Ondokuz Mayıs Üniversitesi Ë̆itim Fakültesi Dergisi, 32 (1). 107-126.

Demirbulak, D. (2000). Veli-öğretmen görüşmeleri ile ilgili bir çalışma. Millî Ë̆gitim Dergisi, (146), 5355.

Demirtaş, H., Üstüner, M., ve Özer, N. (2007). Okul yönetiminde karşılaşılan sorunların öğrenci ve okul ile ilgili değişkenler açısından incelenmesi. Kuram ve Uygulamada Eğitim Yönetimi, 51(51), 421-455.

Dönmez, B. (2001). Okul güvenliği sorunu ve okul yöneticisinin rolü. Kuram ve Uygulamada Eğitim Yönetimi Dergisi, 7(1), 63-74.

Ekiz, D. (2003). Eğitimde Araștırma Yöntem ve Metotlarma Giriş. Ankara: Anı Yayınc1lı.

Gedikoğlu, T. (2005). Avrupa Birliği sürecinde Türk Eğitim Sistemi: Sorunlar ve çözüm önerileri. Mersin Üniversitesi Eğitim Fakültesi Dergisi, 1(1), 66-80.

Güneş, D.Z. ve Kara, S.B.K. (2016). İlkokulların sorunlarının öğretmenler kurulu toplantılarına dayalı olarak incelenmesi. Bartın Üniversitesi Eğitim Fakültesi Dergisi, 5(1), 142-153.

Karip, E. (2004). Eğitim yöneticilerinin yetiştirilmesi ile ilgili politikalar ve uygulamalar. Özel Okullar ve Ĕ̈itim Yönetimi Sempozyumu (25-27 Ocak). Antalya.

Kayıkçı, K. (2001). Yönetici Yetiştirme Sorunu. Milli Eğitim Dergisi, (150), 28-32.

Mestry, R. ve Grobler, B. R. (2004). The training and development of principals to manage schools effectively using the competence approach. ISEA, 32 (3), 2-19. .

Miles, M. B. ve Huberman, A. M. (2016). Nitel Veri Analizi. (Çev. Ed: Sadegül Akbaba Altun ve Ali Ersoy). Ankara: Pegem Akademi.

Özan, M. B. ve Kaya, K. (2009). İlköğretim kurumlarında görev yapan öğretmen ve yöneticilerin kendilerini yenileme ve kariyer basamaklarında yükselme sistemi ile ilgili görüşleri. Fırat Üniversitesi Sosyal Bilimler Dergisi, 19 (1), 97- 112.

Recepoğlu, E. ve Kılınç, A. Ç. (2014). Türkiye'de okul yöneticilerinin seçilmesi ve yetiştirilmesi ve yetiştirilmesi, mevcut sorunlar ve çözüm önerileri (Elektronik versiyon). International Periodical For The Languages, Literature and History of Turkish or Turkic, 9 (2), 1817-1845.

Taş, S. (2010). İlköğretim okullarında sınıfta zaman kaybettiren etkinlikler. Süleyman Demirel Üniversitesi Sosyal Bilimler Enstitüiü Dergisi, (12), 73-93.

Taşdan, M., Tösten, R., Bulut, K. ve Karakaya, V. (2013). Okul yöneticilerinin ilköğretim okullarında karşılaşılan yönetim sorunlarına ilişkin görüşleri. Ë̆itim Bilimleri ve Uygulama, 12 (24), 95-113.

Tösten, R., Han, B. ve Ergül, H. F. (2016). Diyarbakır'daki kamu okullarının yönetim sorunları. EKEV Akademi Dergisi, (65), 433-450.

Türnüklü, A. (2000). Eğitimbilim araştırmalarında etkin olarak kullanılabilecek nitel bir araştırma tekniği: Görüşme. Kuram ve Uygulamada Eğitim Yönetimi Dergisi, 6 (4), 543-559.

Yıldırım, A. ve Şimşek, H. (2013). Sosyal Bilimlerde Nitel Araştırma Yöntemleri. Seçkin Yayıncılık.

Yılmaz, K. ve Altınkurt, Y. (2011). Öğretmen adaylarının Türk eğitim sisteminin sorunlarına ilişkin görüşleri. Uluslararası İnsan Bilimleri Dergisi, 8 (1), 942-973.

\section{Citation Information}

Dağlı, A. \& Han, B. (2017). Okul Müdürlerinin Görüşlerine Göre Diyarbakır İli Eğitim Sorunları ve Çözüm

Önerileri. Dicle Üniversitesi Ziya Gökalp Ë̆gitim Fakültesi Dergisi, 32, 892-904. 